Hamish M. Munro MD FRCA,

Celia C. D'Errico DO, Gillian R. Lauder MD FRCA, Deborah S. Wagner PHARM D, Terri Voepel-Lewis RN MSN, Alan R. Tait PhD

\section{Oral granisetron for strabismus surgery in children}

Purpose: To determine the efficacy of oral granisetron in preventing postoperative vomiting (POV) following strabismus repair in children.

Methods: In a randomized, double-blind, placebo-controlled trial, 73 pediatric patients received either placebo, $20 \mu \mathrm{g} \cdot \mathrm{kg}^{-1}$ or $40 \mu \mathrm{g} \cdot \mathrm{kg}^{-1}$ granisetron po $20 \mathrm{~min}$ before induction of anesthesia. No premedication was given, induction was with halothane and all children breathed spontaneously via a laryngeal mask airway. Maintenance was with isoflurane without the use of opioids. Ketorolac and acetaminophen were used for analgesia. The number of episodes and the severity of vomiting and retching were recorded for the first $24 \mathrm{hr}$ postoperatively, as was the use of rescue antiemetics.

Results: Granisetron $20 \mu \mathrm{gg}^{-1}$ and $40 \mu \mathrm{g}^{\mathrm{kg}} \mathrm{g}^{-1}$ were more effective than placebo in reducing the incidence of POV during the first $24 \mathrm{hr}(29 \%$ in both the granisetron groups vs $84 \%$ in the placebo group, $P<0.05)$. In addition, the number of children experiencing severe vomiting ( 23 episodes) was reduced in the granisetron 20 $\mu \mathrm{g} \cdot \mathrm{kg}^{-1}$ and $40 \mu \mathrm{g} \cdot \mathrm{kg}^{-1}$ groups compared with placebo (4\%, $8 \%$ and $48 \%$ respectively, $\left.P<0.05\right)$. Patients in the granisetron group were discharged home earlier ( $105 \mathrm{~min}$ vs $124 \mathrm{~min}, P=0.04)$. There was no difference in the incidence of POV between the two granisetron groups.

Conclusion: Preoperative oral granisetron in a dose of $20 \mu \mathrm{g} \cdot \mathrm{kg}^{-1}$ provided effective prophylaxis against POV in children undergoing stabismus repair.

Objectif : Déterminer l'efficacité du granisétron, administré par voie orale, à prévenir les vomissements postopératoires (VPO) suivant la correction du strabisme chez des enfants.

Méthode : Lors d'un essai contre placebo, en double aveugle, 73 patients pédiatriques ont reçu soit un placebo, soit $20 \mu \mathrm{g} \mathrm{kg}^{-1}$ ou $40 \mu \mathrm{g} \mathrm{kg}^{-1}$ de granisétron po 20 min avant l'induction de l'anesthésie. Aucune prémédication n'a été administrée, l'induction s'est faite avec de l'halothane et l'anesthésie a été maintenue chez tous les enfants en utilisant la ventilation spontanée au moyen d'un masque laryngé. On a maintenu l'anesthésie avec de l'isoflurane sans employer d'opioìdes. Les analgésiques étaient du kétorolac et de l'acétaminophène. Le nombre et la sévérité des épisodes de vomissements et de haut-le-coeur ont été notés, pendant les vingt-quatre premières heures postopératoires, de même que le recours à des antiémétiques.

Résultats : Le granisétron à $20 \mu \mathrm{g}^{\mathrm{kg}-1}$ et à $40 \mu \mathrm{g} \cdot \mathrm{kg}^{-1}$ a été plus efficace que le placebo en réduisant l'incidence des VPO pendant les vingt-quatre premières heures ( $29 \%$ dans les deux groupes qui ont reçu du granisétron vs $84 \%$ dans le groupe qui a reçu le placebo, $P<0,05$ ). De plus, le nombre d'enfants qui ont eu des vomissements sévères ( $\geq 3$ épisodes) était réduit dans les groupes recevant du granisétron en doses de $20 \mu \mathrm{g} \cdot \mathrm{kg}^{-1}$ et de $40 \mu \mathrm{g} \cdot \mathrm{kg}^{-1}$ à comparer au groupe recevant le placebo ( $4 \%, 8 \%$ et $48 \%$ respectivement, $\left.P<0,05\right)$. Les patients du groupe granisétron ont reçu leur congé plus tôt ( $105 \mathrm{~min}$ vs $124 \mathrm{~min}, P=0,04)$. II n'y a pas eu de différence entre les deux groupes qui ont reçu du granisétron concernant l'incidence des VPO.

Conclusion : L'administration orale préopératoire de granisétron en doses de $20 \mu \mathrm{g} \cdot \mathrm{kg}^{-1}$ prévenait de façon efficace les VPO chez les enfants ayant subi une correction de strabisme.

From the Section of Pediatric Anesthesiology, C. S. Mott Children's Hospital, F3900 Mott Hospital, Box 0211, Ann Arbor, MI 48109. Address correspondence to: Hamish M. Munro MD FRCA, Phone: 313-763-2435; Fax: 313-763-6651; E-mail: hmunro@umich.edu Supported by a grant from SmithKlein Beecham Pharmaceuticals. Presented in part at the annual meeting of the IARS, Orlando, FL. March $7 \cdot 11,1998$.

Accepted for publication October 3, 1998 
$\mathrm{P}$ OSTOPERATIVE nausea and vomiting (PONV) is common after strabismus repair in children, ${ }^{1}$ and may lead to delayed discharge or unanticipated hospital admission. The 5-hydroxytryptamine subtype $3\left(5-\mathrm{HT}_{3}\right)$ antagonists ondansetron and granisetron have been shown to be effective against both chemotherapy-induced and postoperative vomiting in children ${ }^{2-5}$ but are expensive when used intravenously. Rose et al. recently showed that preoperative oral ondansetron administered prior to tonsillectomy was associated with reduced postoperative vomiting (POV) in pre-adolescent children and resulted in cost savings when compared with the use of the iv preparation. ${ }^{6}$ To date, there are no data on the effective dose of an oral preparation of granisetron, and since it can be compounded from tablet form with a long shelf-life, ${ }^{7}$ its use could reduce the cost and wastage when compared with the $i v$ preparation. In this randomized, doubleblind, placebo controlled trial, we compared two doses of oral granisetron, $20 \mu \mathrm{g} \cdot \mathrm{kg}^{-1}$ and $40 \mu \mathrm{g} \cdot \mathrm{kg}^{-1}$ with placebo for the prophylaxis of POV following strabismus repair in children.

\section{Methods}

Following Institutional Review Board approval and written consent from the parents, 76 children ASA physical status 1-2, aged 1-12 yr (mean $5.1 \mathrm{yr}$ ) scheduled for strabismus correction on an outpatient basis, were enrolled. Exclusion criteria included a known allergy to $5-\mathrm{HT}_{3}$ antagonists or recent use of a drug with a known antiemetic effect. All patients were fasted for at least four hours for clear liquids and for six hours for solids. No preoperative sedation was administered. Patients were randomly assigned using computer-generated random numbers to one of three groups. Twenty minutes before induction of anesthesia, all patients received in a doubleblind fashion, placebo, $20 \mu \mathrm{g} \cdot \mathrm{kg}^{-1}$ or $40 \mu \mathrm{g} \cdot \mathrm{kg}^{-1}$ granisetron. Acceptance of the formulation was scored as follows: 1 = accepted readily, 2 = accepted reluctantly, $\mathbf{3}=$ restrained, $\mathbf{4}=$ refused or spat out.

The suspension was prepared in advance by the hospital pharmacy using $1 \mathrm{mg}$ granisetron tablets suspended in Ora-Plus ${ }^{\mathrm{TM}}$ (Paddock Labs, Inc, Minneapolis, $\mathrm{MN}$ ) with strawberry syrup to achieve a concentration of $400 \mu \mathrm{g} \cdot \mathrm{ml}^{-1}$ whereas the placebo was strawberry syrup without the granisetron. The oral formulation was drawn up in syringes and all patients received a standard volume of $0.1 \mathrm{ml} \cdot \mathrm{kg}^{-1}$ with both the anesthesiologist and nurse blinded to its contents.

Anesthesia was induced with halothane and nitrous oxide $66 \%$ in oxygen via face mask. Intravenous access was obtained and a laryngeal mask airway (LMA) was inserted under deep inhalation anesthesia. All patients received $0.5 \mathrm{mg} \cdot \mathrm{kg}^{-1}$ ketorolac in, $10 \mu \mathrm{g} \cdot \mathrm{kg}^{-1}$ glycopyrrolate $i v$, and $20 \mathrm{mg} \cdot \mathrm{kg}^{-1}$ acetaminophen $p r$. Anesthesia was maintained with nitrous oxide and isoflurane and intravenous fluids were administered as per existing protocols to replace preoperative deficits and to provide standard maintenance requirements. At the completion of surgery, the LMA was removed and an oro-gastric tube was inserted to suction the stomach.

Pain was assessed according to a 10 point objective scale ( $1=$ no pain, $10=$ worst pain $)$ and, at the discretion of the post anesthesia care unit (PACU) nurse, was treated with $0.05 \mathrm{mg} \cdot \mathrm{kg}^{-1}$ morphine $i v$ (typically for a score $\geq 5$ ). The time from the end of surgery to first response to commands, first oral intake and discharge readiness were recorded, as well as any episodes of nausea, vomiting and retching. Vomiting was defined as the forceful expulsion of gastric contents, retching was rhythmic contraction of the diaphragm without expulsion of gastric contents. Both were considered as emetic episodes. The severity of emesis was defined as mild ( 1 episode), moderate ( 2 episodes) and severe ( 23 episodes). Children with more than one episode of vomiting or retching were given $0.15 \mathrm{mg} \cdot \mathrm{kg}^{-1}$ metoclopramide $i v$.

The patients were discharged when our standard criteria were met, which includes stable vital signs and minimal pain or emesis. Tolerance of oral fluids was not required before discharge. Twenty-four hours postoperatively, a follow-up telephone call was made to determine the incidence and severity of emesis on the trip home and during the initial $24 \mathrm{hr}$, as well as the use of antiemetic and analgesics and the incidence of side effects associated with $5-\mathrm{HT}_{3}$ antagonists (headache and abdominal pain).

\section{Statistical Methods}

A power analysis performed before the study required 24 patients per group in order to detect a reduction in the incidence of $24 \mathrm{hr}$ emesis of $50 \%$, assuming an incidence of $70 \%$ in the placebo group $(\alpha=0.05 ; \beta=0.20)$. Continuous data were analyzed by one-way ANOVA and nominal data were compared by chi-square and Fisher's exact test where appropriate. All tests were twosided, significance was defined as $P<0.05$.

\section{Results}

Seventy-six children were enrolled, but three refused or spat out the study medication and were excluded from further analysis. There were no differences among the three groups with respect to age, weight, gender, ASA physical status, number of eye muscles operated on, or duration of anesthesia and surgery (Table I). Sixty-two children (85\%) readily accepted 
TABLE I Demographic and Intraoperative Data $[$ mean \pm SD, or mode (range)]

\begin{tabular}{llll}
\hline Group & Placebo & $\begin{array}{l}\text { Granisetron } \\
20 \mathrm{ug}^{-1} \\
(n=24)\end{array}$ & $\begin{array}{l}\text { Granisetron } \\
40 \mathrm{ug}^{-1} \mathrm{~kg}^{-1} \\
(n=24)\end{array}$ \\
\hline Age (yr) & $5.6 \pm 2.9$ & $4.5 \pm 2.3$ & $4.9 \pm 3.3$ \\
Weight (kg) & $22.2 \pm 7.7$ & $21.7 \pm 11.3$ & $20.3 \pm 9.4$ \\
Gender (M/F) & $13 / 12$ & $9 / 15$ & $12 / 12$ \\
$\begin{array}{l}\text { Number of muscles } \\
\text { Duration of } \\
\text { surgery (min) }\end{array}$ & $2(1-4)$ & $2(1-4)$ & $2(1-4)$ \\
$\begin{array}{l}\text { Duration of } \\
\text { anesthesia (min) }\end{array}$ & $41.9 \pm 16.4$ & $47.7 \pm 17.2$ & $45.6 \pm 18.8$ \\
\hline
\end{tabular}

TABLE II Postoperative Data [mean $\pm \mathrm{SD}$, or $\mathrm{n}$ ]

\begin{tabular}{llll}
\hline Group & Placebo & $\begin{array}{l}\text { Granisetron } \\
20 \mu g \cdot \mathrm{kg}^{-1} \\
(n=24)\end{array}$ & $\begin{array}{l}\text { Granisetron } \\
40 \mu g \cdot \mathrm{kg}^{-1} \\
(n=24)\end{array}$ \\
\hline $\begin{array}{l}\text { Time to } \\
\text { awakening (min) }\end{array}$ & $25.0 \pm 17.0$ & $31.0 \pm 20.0$ & $21.0 \pm 17.0$ \\
$\begin{array}{l}\text { Time to oral } \\
\text { fluids (min) }\end{array}$ & $74.0 \pm 33.0$ & $62.0 \pm 25.0$ & $61.0 \pm 27.0$ \\
$\begin{array}{l}\text { Antiemetics } \\
\text { administered }\end{array}$ & 9 & $1^{*}$ & 4 \\
$\begin{array}{l}\text { Opioids } \\
\text { administered }\end{array}$ & 9 & 9 & 8 \\
$\begin{array}{l}\text { Time to discharge } \\
\text { readiness }\end{array}$ & $124.0 \pm 34.6$ & $104.8 \pm 33.9^{*}$ & $104.7 \pm 36.3^{*}$ \\
$\begin{array}{l}\text { Headache } \\
\text { Abdominal pain }\end{array}$ & 8 & 3 & 3 \\
\hline
\end{tabular}

* $P<0.05$ compared with placebo

the study medication, $10(14 \%)$ were reluctant to take it and one child required restraint. There were no differences among groups in time to first response, total iv fluids administered, analgesic requirements or in the incidence of headache or abdominal pain (Table II).

The incidence of in-hospital vomiting was $6 / 24$ $(25 \%)$ in the granisetron $20 \mu \mathrm{g} \cdot \mathrm{kg}^{-1}$ group, $5 / 24(21 \%)$ in the granisetron $40 \mu \mathrm{g} \cdot \mathrm{kg}^{-1}$ group $13 / 25(52 \%)$ in the placebo group $(P<0.05)$. The incidence of vomiting in the first $24 \mathrm{hr}$ was $7 / 24$ (29\%) in both the granisetron $20 \mu \mathrm{g} \cdot \mathrm{kg}^{-1}$ and $40 \mu \mathrm{g} \cdot \mathrm{kg}^{-1}$ groups, compared with $21 / 25$ $(84 \%)$ in the placebo group $(P<0.05)$. In addition, the number of children experiencing severe vomiting $(\geq 3$ episodes) was less in the granisetron $20 \mu \mathrm{g} \cdot \mathrm{kg}^{-1}$ and 40 $\mu \mathrm{g} \cdot \mathrm{kg}^{-1}$ groups than in the placebo group $(1 / 24,2 / 24$ and $12 / 25$ respectively, $P<0.05$ ). Patients in the granisetron groups required fewer rescue antiemetics and were ready for discharge from the PACU earlier $(105 \pm$ $34.3 \mathrm{~min}$ vs $124 \pm 34.6 \mathrm{~min}, P=0.04$ ). There were no differences in the incidence and severity of POV between
TABLE III Incidence and Severity of Postoperative Vomiting in the first $24 \mathrm{hr}[\mathrm{n}]$

\begin{tabular}{|c|c|c|c|}
\hline Group & $\begin{array}{l}\text { Placebo } \\
(n=25)\end{array}$ & $\begin{array}{l}\text { Granisetron } \\
20 \mathrm{ng} \cdot \mathrm{kg}^{-1} \\
(n=24)\end{array}$ & $\begin{array}{l}\text { Granisetron } \\
40 \mu g \cdot \mathrm{kg}^{-1} \\
(n=24)\end{array}$ \\
\hline \multicolumn{4}{|l|}{ incidence of emesis } \\
\hline in-hospital & 13 & $6 *$ & $5^{*}$ \\
\hline journey home & 14 & $1 *$ & $1 *$ \\
\hline home emesis & 12 & $1 *$ & 3 * \\
\hline $24 \mathrm{hr}$ cmesis & 21 & $7 *$ & $7 *$ \\
\hline \multicolumn{4}{|l|}{$\begin{array}{l}\text { severity of emesis } \\
\text { none }\end{array}$} \\
\hline $\begin{array}{l}\text { (0 episodes) } \\
\text { mild }\end{array}$ & 4 & $17^{*}$ & $17^{*}$ \\
\hline $\begin{array}{l}\text { ( } 1 \text { episode) } \\
\text { moderate }\end{array}$ & 7 & 6 & 3 \\
\hline $\begin{array}{l}\text { (2 episodes) } \\
\text { severe }\end{array}$ & 2 & 0 & 2 \\
\hline (3 episodes) & 12 & $1^{*}$ & $2 *$ \\
\hline
\end{tabular}

$\star P<0.05$ compared with placebo

the $20 \mu \mathrm{g} \cdot \mathrm{kg}^{-1}$ and $40 \mu \mathrm{g} \cdot \mathrm{kg}^{-1}$ granisetron dose. No children were admitted to hospital due to prolonged POV.

\section{Discussion}

This study showed that preoperative oral granisetron reduced both the incidence and severity of POV compared with placebo in the first $24 \mathrm{hr}$ following outpatient strabismus surgery in children. However, it should be noted that, despite the equal efficacy of both doses of granisetron in reducing the incidence of POV compared with placebo, we were unable to detect any further differences in the incidence between individual doses. Although this may be a true observation, the possibility of a type II error should not be ignored.

The doses of $20 \mu \mathrm{g} \cdot \mathrm{kg}^{-1}$ and $40 \mu \mathrm{g} \cdot \mathrm{kg}^{-1}$ were chosen based upon previously published papers. Fujii et at. demonstrated that $40 \mu \mathrm{g} \cdot \mathrm{kg}^{-1}$ granisetron iv was the optimal dose for preventing emesis following strabismus repair and tonsillectomy. ${ }^{8}$ The same authors showed that $40 \mu \mathrm{g} \cdot \mathrm{kg}^{-1}$ granisetron ip was more effective than placebo, metoclopramide and droperidol in reducing the incidence of POV after pediatric surgery. ${ }^{5}$ In addition, Cieslak $e t a l$. showed that a dose of $10 \mu \mathrm{g} \cdot \mathrm{kg}^{-1}$ iv was ineffective in the prophylaxis of pediatric PONV, whereas $40 \mu \mathrm{g} \cdot \mathrm{kg}^{-1} i v$ reduced the incidence of PONV from $42 \%$ in the control group to $9 \%{ }^{4}$ In this study we chose a lower $20 \mu \mathrm{g} \cdot \mathrm{kg}^{-1}$ dose as it was cheaper.

The antiemetic action of the $5-\mathrm{HT}_{3}$ antagonists is thought to be mediated by blocking the action of serotonin at receptor sites both centrally within the chemoreceptor trigger zone (CTZ) and the nucleus tractus solitarius, and peripherally on the vagal afferents from the gastrointestinal tract. Granisetron is a more selective 
$5-\mathrm{HT}_{3}$ receptor antagonist than ondansetron with a longer duration of action. ${ }^{9}$ Our results showed a high incidence of POV in the placebo group (84\%) which is comparable to other studies of strabismus surgery where a prophylactic antiemetic was not used. ${ }^{10}$ Many factors contribute to PONV following strabismus surgery, including the use of opioids, ${ }_{11}^{11}$ propofol, ${ }^{12}$ nitrous oxide $^{13}$ and various antiemetics, ${ }^{14}$ and this makes direct comparison of our results with other studies difficult. However, Shendel et al. showed that $150 \mu \mathrm{g} \cdot \mathrm{kg}^{-1}$ ondansetron iv reduced the incidence of PONV during the first 24 postoperative $h r$ to over half that of the placebo group (34.5\% vs $71.7 \%$ ), whereas metoclopramide had no effect. ${ }^{10}$ In our study, early or pre-discharge emesis was reduced by approximately $50 \%$ by the use of granisetron. However, of note was the extremely low incidence of emesis after discharge from hospital which supports the long duration of action of $5-\mathrm{HT}_{3}$ antagonists that has been demonstrated with ondansetron. ${ }^{10}$ The need for rescue antiemetics was lower in the treatment groups and time to discharge readiness was nearly $20 \mathrm{~min}$ earlier in the granisetron groups $(P<0.05)$ which may have economic implications. The side effects known to be associated with $5-\mathrm{HT}_{3}$ receptor antagonists include headache and abdominal pain. There was no difference among groups regarding these side effects.

Granisetron has been associated with high costs. However, the use of tablets to prepare an oral formulation suitable for children resulted in reduced costs with ondansetron. ${ }^{6}$ The flavoured syrup was prepared using $\mathrm{l} \mathrm{mg}$ tablets to achieve a concentration of $400 \mu \mathrm{g} \cdot \mathrm{ml}^{-1}$ as described by Quercia $e t a l^{7}$ This extemporaneously prepared formulation is stable for up to 30 days at temperatures between 5 and $24^{\circ} \mathrm{C}$ and can therefore be used for multiple dosing with little wastage. The $1 \mathrm{mg}$ tablet costs US\$31.17 compared with $\$ 92.02$ for $1 \mathrm{mg}$ of the ip preparation. This contrasts with ondansetron which is available in a commercially prepared oral syrup (4 $\mathrm{mg} \cdot 5 \mathrm{ml}^{-1}$ ) at $\$ 2.22 \cdot \mathrm{ml}^{-1}$. If one assumes that granisetron and ondansetron have similar outcomes, then a dose of oral ondansetron $150 \mu \mathrm{g} \cdot \mathrm{kg}^{-1}$ is comparable in price $\left(\$ 0.42 \cdot \mathrm{kg}^{-1}\right.$ vs $\left.\$ 0.63 \cdot \mathrm{kg}^{-1}\right)$. This is in sharp contrast to metoclopramide and droperidol which each cost less that $\$ 0.80$ per multidose vial.

In conclusion, this study showed that $20 \mu \mathrm{g} \cdot \mathrm{kg}^{-1}$ granisetron po administered $20 \mathrm{~min}$ before surgery was effective in reducing the incidence and severity of POV following strabismus repair in children, resulting in earlier time to discharge from hospital. Despite this, the relatively high cost of granisetron needs to be considered when choosing this antiemetic and balanced against potential benefits in terms of patient comfort and reduced hospital stay.

\section{References}

1 Watcha MF, White PF. Postoperative nausea and vomiting. Its etiology, treatment and prevention. Anesthesiology 1992; 77; 162-84.

2 Craft $A W$, Price $L$, Eden $O B$, et al. Granisetron as antiemetic therapy in children with cancer. Med Pediatr Oncol 1995; 25: 28-32.

3 Furst SR, Rodarte A. Prophylactic antiemetic treatment with ondansetron in children undergoing tonsillectomy. Anesthesiology 1994; 81: 799-803.

4 Cieslak GD, Watcha MF, Phillips $M B$, Pennant JH. The dose-response relation and cost-effectiveness of granisetron for the prophylaxis of pediatric postoperative emesis. Anesthesiology 1996; 85: 1076-85.

5 Fujii $Y$, Tanaka $H$. Prophylactic therapy with granisetron in the prevention of vomiting after paediatric surgery. A randomized, double-blind comparison with droperidol and metoclopramide. Paediatr Anaesth 1998; 8: 149-53.

6 Rose JB, Brenn BR, Corddry DH, Thomas PC. Preoperative oral ondansetron for pediatric tonsillectomy. Anesth Analg 1996; 82: 558-62.

7 Quercia RA, Zhang J, Fan C, Chow MSS. Stability of granisetron hydrochloride in an extemporaneously prepared oral liquid. Am J Health-Syst Pharm 1997; 54: 1404-6.

8 Fujii $\Upsilon$, Tanaka H, Toyooka $H$. Granisetron reduces vomiting after strabismus surgery and tonsillectomy in children. Can J Anaesth 1996; 43: 35-8.

9 Yarker $X_{E}$, McTavish D. Granisetron. An update of its therapeutic use in nausea and vomiting induced by antineoplastic therapy. Drugs 1994; 48: 765-93.

10 Shende D, Mandal NG. Efficacy of ondansetron and metoclopramide for preventing postoperative emesis following strabismus surgery in children. Anaesthesia 1997; 52: 489-500.

11 Munro HM, Riegger LQ Reynolds PI, Wilton NCT, Lewis $I H$. Comparison of the analgesic and emetic properties of ketorolac and morphine for paediatric outpatient strabismus surgery. Br J Anaesth 1994; 72: 624-8.

12 Weir PM, Munro HM, Reynolds PI, Lewis IH, Wilton NCT. Propofol infusion and the incidence of emesis in pediatric outpatient strabismus surgery. Anesth Analg 1993; 76: 760-4.

13 Snellen FT, Vanacker B, Van Aken H. Propofol-nitrous oxide versus thiopental sodium-isoflurane-nitrous oxide for strabismus surgery in children. J Clin Anesth 1993; 5: 37-41.

14 Birch $A A$, Kovarik $D, M c G r a w ~ T$, et al. Immediate and delayed post-operative vomiting in pediatric strabismus surgery. Effects of antiemetic therapy. Anesth Analg 1998; 86: S394. 